\title{
Comparative Analysis of Traditional Production Systems with Flexible Manufacturing Systems
}

\author{
Tarkan Koca ${ }^{*}$, Serhat Aksungur ${ }^{2}$
}

Accepted $3^{\text {rd }}$ September 2016

\begin{abstract}
Nowadays technology is developing rapidly and the adaptation of emerging technology to daily life is very fast. Within this context, production technologies are developing rapidly and parallel to this production instrument's costs are decreased. In this way, producers can make investments more easily by getting current technology.

In parallel with industrial development, some parameters such lost time, labor, raw materials must reduce. When considering expected product variety, especially modification on the produced product is a difficult process. Revising of the production system according to the final product is substantially increased the amount of lost time. In addition, in this revision process previously realized investment is becoming inert and this quite increases costs. It is almost impossible the creation of a separate production line for each product in a company which has a lot of variety of products. Nowadays in this needed speed production process, instead of conventional production systems flexible manufacturing systems began to be preferred in the industry.

In this study, functions, components and the overall structures of the flexible manufacturing systems are described. Differences between traditional production systems and flexible manufacturing systems, and the advantages relative to each other were examined. In the study, Flexible Manufacturing Systems Laboratory within the Inonu University Arapgir Vocational High School was taken as an example.
\end{abstract}

Keywords: Flexible manufacturing systems, traditional production systems, factory organization.

\section{Introduction}

One of the major environmental factors that directly affect activity of the business is the economic system adopted by the country where the business [1].

Industrial businesses are organizations that meet the demands of customers, carry out the production function for it. Businesses should develop and establish a proper system for needs when performing their production.

Production Process is a process in which the materials are introduced as output after certain changes. Other processing activated where a process finished. As soon as a process starts the previous work is completed. Operations can be specified as a node and all the nodes constitute input-output system. [2]

\section{Traditional Manufacturing Systems}

The construction of traditional manufacturing systems is shown in Figure 1.

\footnotetext{
${ }^{1}$ Mechatronic Department, İnönü University, Campus, Malatya/Turkey

*Corresponding Author: Email: tarkan.koca@inonu.edu.tr
}

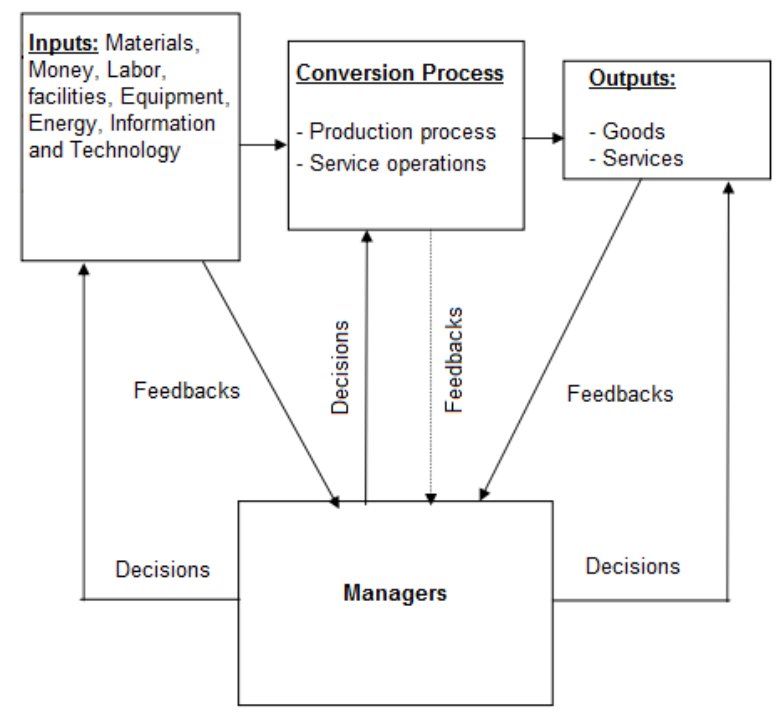

Figure 1. Traditional manufacturing systems [1]

It can be said to show a hierarchical structure of production systems. It is often used in the creation of this system is a hierarchical design approach. This approach can generate significant demand and limited production capability well in environments in which the solutions, but not enough. Classic hierarchical type of production structures, the not fully compatible with dynamic environment and leads to degradation in performance.

Traditional production types are summarized in comparison in Table 1: 
Table 1. Features of Traditional Production System [1]

\begin{tabular}{|c|c|c|c|c|}
\hline Features & $\begin{array}{l}\text { workshop- } \\
\text { type } \\
\text { production }\end{array}$ & $\begin{array}{l}\text { Flow-type } \\
\text { production }\end{array}$ & $\begin{array}{l}\text { Project- } \\
\text { type } \\
\text { production }\end{array}$ & $\begin{array}{l}\text { continuous- } \\
\text { type } \\
\text { production }\end{array}$ \\
\hline $\begin{array}{l}\text { Machine } \\
\text { Types }\end{array}$ & $\begin{array}{l}\text { Flexible, } \\
\text { general- } \\
\text { purpose }\end{array}$ & $\begin{array}{l}\text { Special, } \\
\text { Mono } \\
\text { functional }\end{array}$ & $\begin{array}{l}\text { General- } \\
\text { purpose, } \\
\text { Mobile }\end{array}$ & Special \\
\hline $\begin{array}{l}\text { Process } \\
\text { Design }\end{array}$ & $\begin{array}{l}\text { Functional } \\
\text { type } \\
\text { Process type }\end{array}$ & $\begin{array}{l}\text { Long headed } \\
\text { workflow }\end{array}$ & $\begin{array}{l}\text { Project } \\
\text { type or } \\
\text { Fixed } \\
\text { Workflow }\end{array}$ & $\begin{array}{l}\text { Product-based } \\
\text { business } \\
\text { flow }\end{array}$ \\
\hline $\begin{array}{l}\text { Preparation } \\
\text { Time }\end{array}$ & $\begin{array}{l}\text { Long } \\
\text { Variable }\end{array}$ & Long & Variable & Very Long \\
\hline Employees & $\begin{array}{l}\text { Mono } \\
\text { function; } \\
\text { Multifunction } \\
\text { (one man + } \\
\text { one machine) }\end{array}$ & $\begin{array}{l}\text { One function; } \\
\text { Less talented }\end{array}$ & $\begin{array}{l}\text { Single- } \\
\text { function, } \\
\text { capable } \\
\text { (One man } \\
+\quad \text { one } \\
\text { machine) }\end{array}$ & $\begin{array}{l}\text { Very few } \\
\text { employees }\end{array}$ \\
\hline Stocks & $\begin{array}{l}\text { Stock in large } \\
\text { quantities for } \\
\text { diversity }\end{array}$ & $\begin{array}{l}\text { A large } \\
\text { amount of } \\
\text { stock to } \\
\text { provide buffer } \\
\text { storage }\end{array}$ & $\begin{array}{l}\text { Variable; } \\
\text { Generally } \\
\text { for raw } \\
\text { materials }\end{array}$ & $\begin{array}{l}\text { Low-process } \\
\text { stock }\end{array}$ \\
\hline Lot Size & $\begin{array}{l}\text { Small- } \\
\text { medium }\end{array}$ & $\begin{array}{l}\text { Larger } \\
\text { amounts }\end{array}$ & $\begin{array}{l}\text { Small } \\
\text { amounts }\end{array}$ & Not applicable \\
\hline $\begin{array}{l}\text { Production } \\
\text { Time for } \\
\text { Each Unit }\end{array}$ & $\begin{array}{l}\text { Long, } \\
\text { variable }\end{array}$ & Short, hard & $\begin{array}{l}\text { Long, } \\
\text { variable }\end{array}$ & Short, hard \\
\hline
\end{tabular}

Rapid changes in the technologies increase the efficiency of computer in the production and positive role of being used mathematical models in the production have attracted the attention of business owners and managers.

Some developments emerging in production can be summarized as follows:

- Computer Aided Manufacturing System

- Flexible Manufacturing Systems

- Material Requirements Planning

- Manufacturing Resource Planning

- JIT Production System

- $\quad$ Synchronized Manufacturing

\section{Flexible Manufacturing system}

Flexible manufacturing systems is defined as the production process can respond, automation and technology-intensive production is done, can be quickly directed to the production of production factors, the products are delivered to customers on time and can be rapidly respond to changes [3].

General characteristics of flexible manufacturing systems can be listed as follows:

- $\quad$ FMS can be used in business which has more varieties of products.

- $\quad$ FMS is used to produce different parts that in the same group.

- It includes general-purpose machinery and machine tools. Small scale changes can be made in the machine/equipment to produce different parts.

- Finished products, semi-finished goods and raw materials are able to move with automatic band and the carrier.

- A main computer controls the general-purpose machinery/equipment and material transport system.

- Production of different parts is possible with automatic changes on the machine.

- Staff intervention on production is minimized.

- From raw material input to finished product output, all process such as quality control, design, production are carried out the basis automation.

The definitions contained in different sources of FMS are as follows:[4]:

- $\quad$ FMS is considered as the application of the Computer Integrated Manufacturing (CIM) concept, which composed from Computer Aided Design (CAD), Computer Aided Manufacturing (CAM) and Computer Aided Process Planning (CAPP).

- FMS is an automated production type controlled by computers which designed for to produce more than one type parts effectively, consisting of the semiindependent workstations and material handling systems.

Main factors affecting the level of flexibility of a business can be listed as follows:

- Work Organization,

- Production Planning and Control Systems,

- Manufacturing Technology,

- Utilization Level of Computer Technology.

\section{Flexible Manufacturing System Modules at Arapgir Vocational School}

General view of Flexible Manufacturing Systems Laboratory

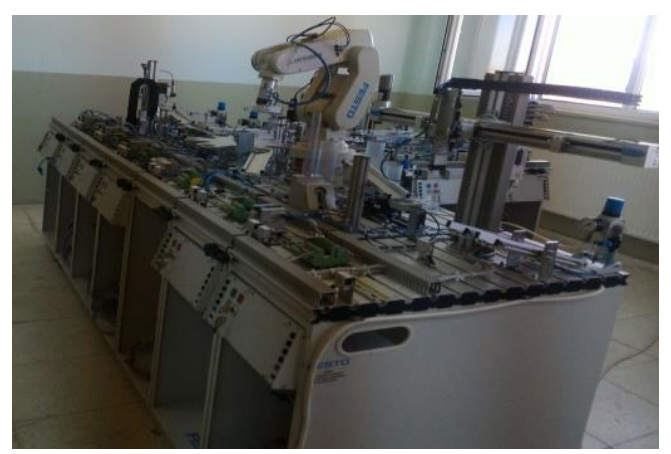

Figure 2 General wiev (front) 


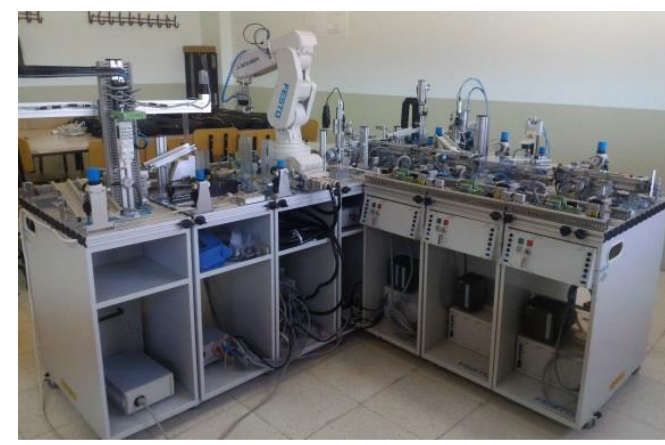

Figure 3. General wiev (back)

\subsection{Distributing Station}

The Distributing station separates work pieces [5].

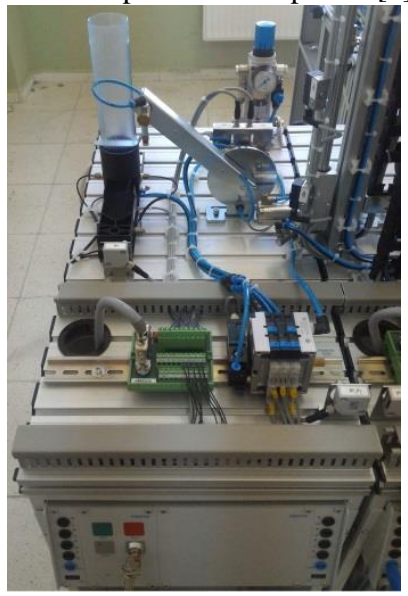

Figure 4. Distributing station

\subsection{Testing Station}

The Testing station detects the various properties of the work pieces inserted into it. It differentiates work pieces with the aid of an optical and a capacitive sensor [5].

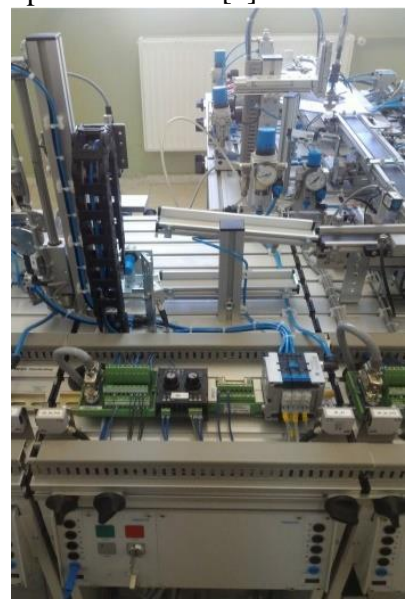

Figure 5. Testing station

\subsection{Separating Station}

The Separating station differentiates work pieces based on their drilled hole depth and separates them into two different material flow directions [5].

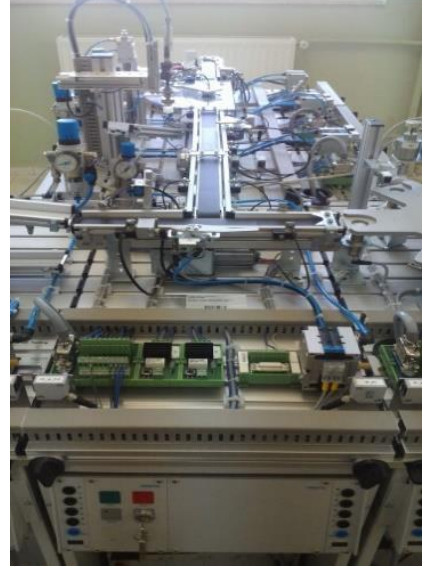

Figure 6. Separating station

\subsection{Processing Station}

In the Processing station, work pieces are tested and processed on a rotary indexing table. On the rotary indexing table, the work pieces are tested and drilled in two parallel processes. A solenoid probe checks that the work pieces are inserted in the correct position. During drilling, the work piece is clamped. Finished work pieces are passed on via the electrical sorting gate [5].

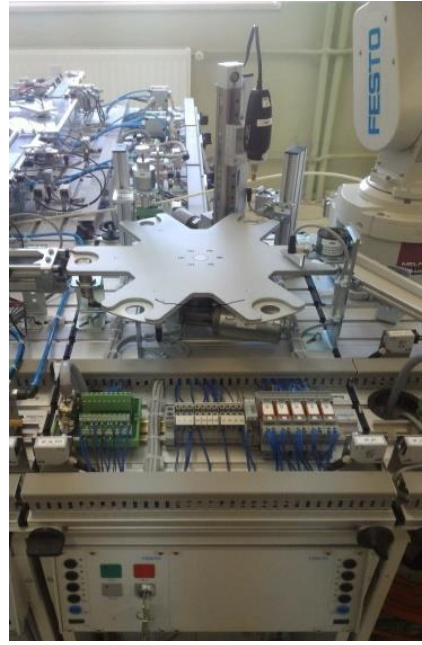

Figure 7. Processing station

\subsection{Robot Station with MPS® Modules}

This equipment level is created based on the basic design of the MPS ${ }^{\circledR}$ robot station and the two robot handling and robot assembly modules as a introduction to industrial robotics. The upstream station feeds the bodies of the pneumatic cylinders to be assembled to the robot via a slide. The robot determines the orientation of the bodies and places them in the assembly holder in the correct orientation. It takes the piston from the pallet and assembles it in the body. Controlled magazines feed the piston springs and cylinder end caps to the robot. The fully assembled pneumatic cylinder is then placed on a slide [5]. 


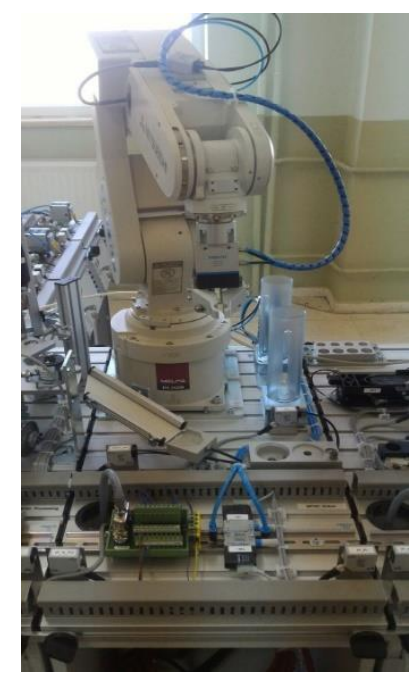

Figure 8. Robot station with MPS $®$ modules

\subsection{Assembly Station}

The assembly station works in conjunction with the robot station. It supplies cylinder components for the assembly process [5].

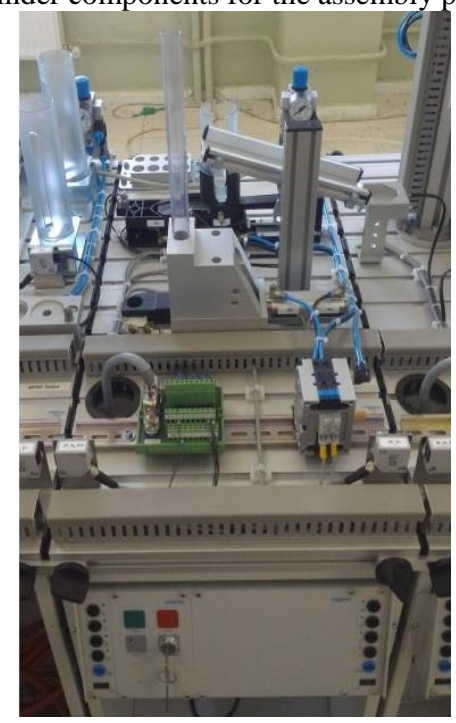

Figure 9. Assembly station

\subsection{Handling Station}

The Handling station, electrical, is equipped with a flexible twoaxis handling device [5].

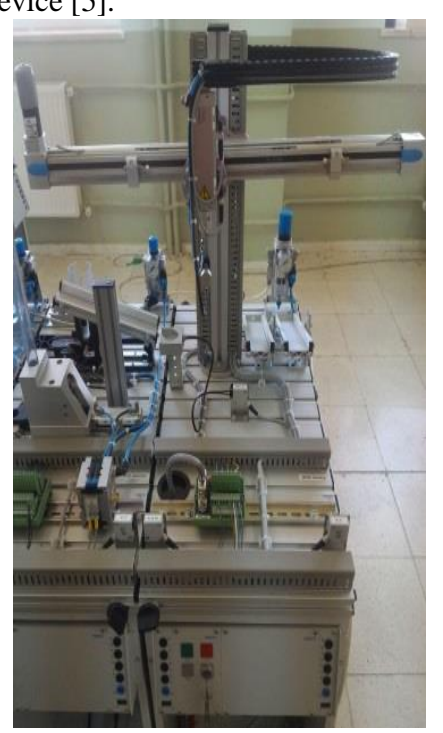

Figure 10. Handling station

\subsection{Pick \& Place Station}

The Pick\&Place station is equipped with a two-axis Pick\&Place module. Work piece housings placed on the conveyor are detected by an optical diffuse sensor. The work piece is transported to the pneumatic separator on the conveyor and detected by a second diffuse sensor. The Pick\&Place module picks up a work piece insert from the slide and places it on the work piece housing. The complete work piece (housing and insert) is released by the separator and transported to the end of the conveyor [5].

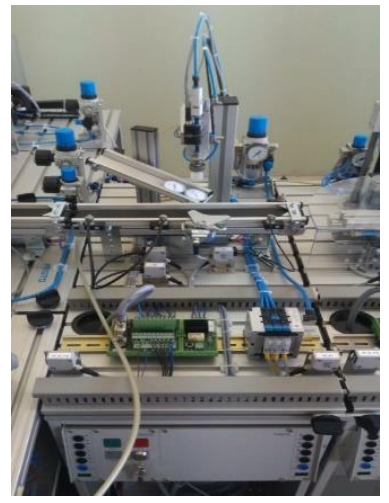

Figure 11. Pick \& Place station

\subsection{Fluidic Muscle Press Station}

The Fluidic Muscle Press station presses work piece inserts into the housings. The rotary/linear actuator (transfer device) moves the housing with the insert placed on it under the press. The pneumatic muscle performs the pressing operation. The finished work piece is then transported to the transfer position [5].

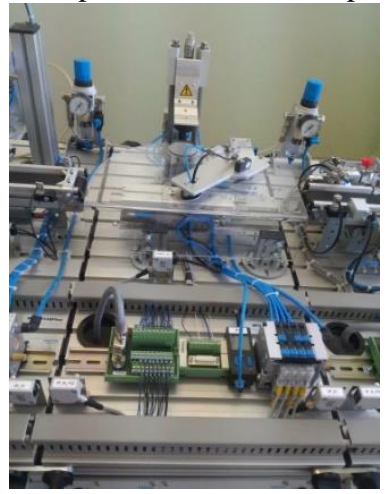

Figure 12. Fluidic Muscle Press station

\subsection{Sorting Station}

The Sorting station sorts work pieces onto three slides [5].

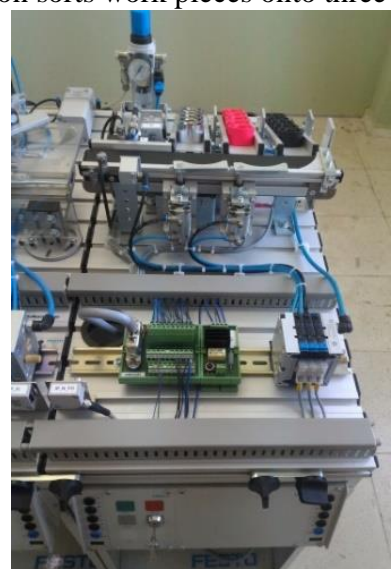

Figure 13. Sorting station 


\section{Conclusion}

In this study, images of the equipment, experiment sets are designed by Festo Didactic training purposes. Each module can be matched with other modules. In this way it is possible to obtain improved diversity of the final product.

The manufacturing sector is constantly evolving according to evolving technology and growing needs. Requested product diversity has led to become outmoded of a single type production line. Therefore, instead of building new production lines to produce different types of the same product, revising this line is easier. In this regard with flexible production systems efficient results are obtained. Despite the high investment costs, in the long term it is seen that provided gain at costs and time.

\section{Acknowledgements}

We owe a debt of thanks to Selcuk University.

\section{References}

[1] M . Doğan, İşletme Ekonomisi ve Yönetimi, Genişletilmiş 2. Bask1, İzmir, 2002.

[2] M. H. Demir, Ş. Gümüşoğlu, Üretim İşlemler Yönetimi, Gözden Geçirilmiş, Genişletilmiş 5. Baskı, Beta Basım Yayım Dağıtım A.S., İstanbul, 1998.

[3] M. Tekin, B. Atamak, "Esnek Üretim Sistemleri ve Esnek Üretim Sistemleri ile İlgili Örnek Uygulamalar", I. Ulusal Üretim Araştırmaları Sempozyumu, İstanbul, 1997.

[4] N. Atalay, D. Birbil, N. Demir, Ş. Yıldırım, KOBI'lerin Esnek Üretim Sistemleri Yönünden İrdelenmesi ve Bir Uygulama, MPM Yayınları, n:632, Ankara, 1998.

[5] (15.06.2016) http://www.festo-didactic.com/int-en/

[6] Festo Didactic: "Learning System for Automation and Communications", "Modular Production System", Training Documentation, 2001 